\title{
Transnational Muslims in American Society
}

Amina Beverly McCloud

Gainesville: University of Florida Press, 2006. 161 pages.

In post-9/11 America, the necessity for a comprehensive study of transnational Muslim communities, as well as their identities and dynamics within American society, is filled by Aminah Beverly McCloud's Transnational 
Muslims in American Society. This comprehensive study examines a crosssection of Muslim communities in diaspora and exile, from the Palestinians to the Iranians to the very small community of Muslim Chinese. The author's examination, which loosely relies on notoriously vague immigration records, first-person interviews, and clever anecdotes, is also coupled with a general history and overview of Islam and the individual communities. The brief histories of each community and its ethnic, cultural, and Islamic idiosyncrasies, placed at the beginning of each chapter, are particularly helpful. In addition, her nuanced analyses of women's positions in the contexts of their own communities provides an important depth to the study.

The book begins with an "Introduction to Immigrant American Muslims," an essentially lengthy abstract of the book, and then transitions to chapter 2, "A Nation of Immigrants, Stereotypes, Imaginations." Here, she conceptualizes the general American immigrant experience and then recontextualizes and extends popular arguments for the creation of the Arab "Oriental" or "Other" in the context of early anthropology and travel literature related to the Islamic world (p. 21). Her discussion of the media in this segment adds to earlier discussions of media portrayals of Muslims by such scholars as Edward Said and commentary immediately following the resurgence of the "Muslim Other" in the post-9/11 period. Particularly helpful for those unfamiliar with Islam, as well as students and professors teaching general sociology and religion courses, is the final segment of the text's introductory core, "Brief Introduction to Islam" (pp. 27-42), which enables the lay person to read the rest of the text critically.

The first study, "South Asian Muslims," is a coupling of two chapters on South Asian history and culture. Here, she discusses the emergence of a South Asian population in the United States, specifically one originating from India and Pakistan, and how it functions in its transnational context. She notes that the construction of identity is centered upon the family and that, as regards assimilation and the creation of a hyphenated identity, these Muslims often have to resituate themselves in the social sphere, outside the caste system's traditional parameters (p. 57), which can be problematic at times. She emphasizes the community's social constructs, as opposed to how their identities are constructed as South Asian Muslims, and how they maneuver through American society as hyphenated Muslims.

Most readers will be interested in "Islam and the Arabs," a continuation of earlier chapters on "Brief Introduction to Islam" and "Arab Muslims and the United States," all of which analyze current events and the growing popularity of Arab-American studies. Islam, as McCloud 
points out, is widely understood to be an exclusively Arab construction; thus, Arab identity is seen as intrinsically linked to it, although this is not necessarily true (p. 72). There is a distinct overlap between the chapters on South Asian and Arab Muslim communities, something from which sociologists and anthropologists could elicit more. Particularly interesting in this chapter, however, is the author's delving into the national identities of Arab Muslims and looking at such particular cases of immigration and transnational identity as that of Palestinian Americans, who exist in an uncomfortable limbo as refugees and in a diaspora. In the American consciousness, they are anti-Israel and even outside the Occupied Territories; in addition, Palestinian-American children are raised with a hyper-political and polarized mindset that sets them apart from their Arab-American peers (p. 89). For them, constructing the "Arab" other is particularly acute as the second Intifada rages on and Hamas acquires more political legitimacy.

McCloud contextualizes the Iranian Americans as a transnational group (the "philosopher poets") that is often vilified in the media. Although South Asian and Arab Muslims outnumber Iranians in the United States, the prevalent American image of Iranians is associated with the embassy hostage crisis of the early 1980s. Not unlike the Palestinian-American experience, the Iranian-American experience can be contextualized as a different kind of transnational experience in that it is not immigration so much as it is immigration coupled with exile (p. 103). The recent influx of Iranian/Persian Muslims (some choose to identify as either/or) (p. 101) has made the study of transnational identity construction far more compelling, while Iranian Americans continue to try to overcome the superficial identity created by the media in the streets of Tehran in 1979.

Finally, the book looks briefly at the Muslim Chinese and Muslim Somali communities, both of which are particularly fascinating. The first community is a virtually unknown facet of Muslim-American culture, for Americans associate being Chinese with fortune cookies and restaurants, not the hijab and a rich Muslim ancestry due to the Silk Road. Muslim Somalis, like their Muslim Chinese counterparts, are also a minority within their own racial group. Oftentimes grouped together with African Americans, these intensely lineage-oriented people struggle to create a concrete identity that is exclusively Somali and Muslim.

McCloud makes an impassioned conclusion to her study of the current position of Muslim Americans as a hyphenated identity in the United States and offers projections as to the community's future. This edge to her schol- 
arly voice makes this a unique and timely text: it is at once a text written for the classroom and for the Muslim-American community at large.

Alexandra Jerome

Ph.D. Candidate, Department of American Studies The College of William and Mary, Williamsburg, Virginia 